\title{
Comparative Study of 1,5-Dinitrogen Schiff Bases as Potential Ligands in Palladium-Catalyzed Allylic Alkylation
}

\author{
Dragan Šepac, Marin Roje, Zdenko Hameršak, and Vitomir Šunjić*
}

\author{
Key words \\ ethylidenes \\ conformation \\ $\mathrm{Pd}^{\mathrm{II}}$ complexes \\ allylic alkylation
}

\begin{abstract}
Ruđer Bošković Institute, P.O.B. 180, 10002 Zagreb, Croatia
RECEIVED APRIL 12, 2002; REVISED MARCH 7, 2003; ACCEPTED MARCH 11, 2003

1-(2'-Pyrido and 2'-quinolino)-(1R)-arylethylamino)-ethylidenes (7-12) were prepared as potential ligands in $\mathrm{Pd}^{\mathrm{II}}$ catalytic complexes for enantioselective allylic alkylation of 1,3-diphenyl1-acetoxy-propene-2 (15). Alkylation with palladium complexes of 7-12 yielded 1,3-diphenyl1-dimethylmalonyl-propene-2 (14) with enantioselectivity up to $55 \%$ e.e. Enantioselectivity is discussed in view of the results recently reported for structurally related 1,5-bidentate dinitrogen ligands of $C_{1}$ symmetry. Reversal of enantioselectivity observed for the ligands $\mathbf{1 0}$ and $\mathbf{1 1}$ is attributed to the inversion of steric requirements in the second coordination sphere of their catalytic complexes.
\end{abstract}

\section{INTRODUCTION}

Chiral bidentate nitrogen ligands proved highly efficient in a various homogeneous catalytic processes; such as hydrosylilation of ketones, ${ }^{1}$ cyclopropanation of alkenes, ${ }^{2}$ Diels-Alder reaction, ${ }^{3}$ Heck reaction, ${ }^{4}$ allylic aminations, ${ }^{5}$ and allylic alkylations. ${ }^{6-10}$ Recent papers have confirmed versatility of the asymmetric allylic alkylation, Scheme 1,6 as the synthetic procedure for enantioselective formation of $\mathrm{C}-\mathrm{C}$ bond in acyclic ${ }^{11-15}$ and cyclic ${ }^{16}$ substrates, or in its intramolecular variant. ${ }^{17}$
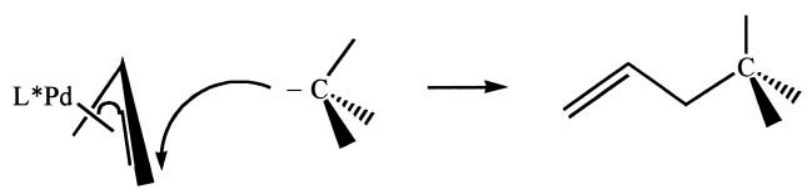

Scheme 1.

Despite of the large number of reports dealing with the activity and enantioselectivity of palladium catalytic systems in allylic alkylations, only a couple of studies was reported on the activity of $C_{1}$ symmetric 1,5-dinitrogen ligands. ${ }^{18,19}$ Prompted by the results published for quinolino-oxazoline ligands $\mathbf{1 a - 1 c},{ }^{19}$ the representatives of $C_{1}$ symmetric 1,5-bidentate dinitrogen ligands, we report here with the results of comparative study of allylic alkylations by the palladium complexes of chiral Schiff bases, enamines of $\alpha$-aryl-2-(2'-pyrido, or 2'-quinolino)-acetophenone 7-12.

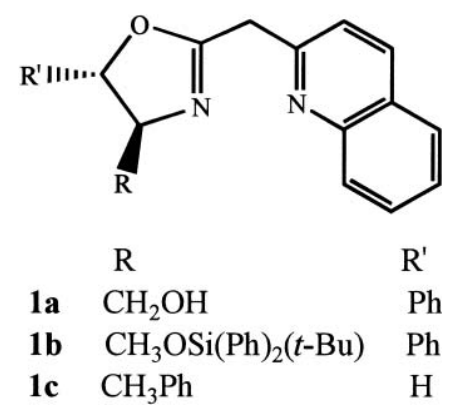

Formulae 1a-1c

\footnotetext{
* Author to whom correspondence should be addressed. (E-mail: sunjic@irb.hr)
} 
1-Arylmethylimines of pyridyl or quinolyl-acetophenones 7-12 are characterized by their conformational flexibility, presence of the large aromatic and heteroaromatic units, and by the imine-enamine equilibrium. We have already reported preparation of some representatives, on their $\mathrm{CD}$ and conformational properties, ${ }^{20,21}$ as well as the results of enantioselective cyclopropanation with their $\mathrm{Cu}^{\mathrm{I}}$ complexes. ${ }^{22}$

\section{EXPERIMENTAL}

IR: Perkin Elmer 297 spectrometer for $\mathrm{KBr}$ pellets, if not stated otherwise. ${ }^{1} \mathrm{H}$ and ${ }^{13} \mathrm{C}$ NMR: Varian Gemini XL 300 spectrometer for $\mathrm{CDCl}_{3}$ solutions, $\delta$ in ppm relative to TMS as internal reference, and $J$ in Hz. HPLC: HP 1050 chromatograph with C18 RP (Nucleosil RP-18, 250×4.6 mm) reverse phase column; separation was monitored by HP $1050 \mathrm{UV}$ detector set up at $254 \mathrm{~nm}$ and connected to HP 3396A integrator. M.p.: Electrothermal Apparatus, are not corrected. Optical rotations: Optical Activity AA-10 Automatic Polarimeter in a $1 \mathrm{dm}$ cell; $c$ in g/100 ml.

$[\operatorname{Pd}(\text { allyl }) \mathrm{Cl}]_{2}$, and other commercially available compounds were purchased from Aldrich, compounds 7-10, and $\mathbf{1 2}$ have been prepared as reported..$^{21,22}$ All commercial reagents were used as received.

During usual workup all organic extracts were dried over $\mathrm{Na}_{2} \mathrm{SO}_{4}$ or $\mathrm{MgSO}_{4}$ and evaporated in vacuo on a Büchi rotavapor.

\section{2-(2'-Quinolino)-2,6-dimethoxy-acetophenone (6)}

All manipulations were performed in dry argon atmosphere. 2-Methyl-quinoline $(1.0 \mathrm{~g}, 7.0 \mathrm{mmol})$ was added dropwise under stirring over $5 \mathrm{~min}$ period at $-10^{\circ} \mathrm{C}$ to the solution of $\mathrm{n}$-BuLi (2.5 M in n-hexane; $3.1 \mathrm{ml}, 7.7 \mathrm{mmol})$, in dry ether $(10 \mathrm{ml})$. Reaction mixture was stirred for $2 \mathrm{~h}$, and at the same temperature added benzoate 3 (1.51 g, 7.7. mmol). After $20 \mathrm{~h}$ stirring at ambient temperature i- $\mathrm{Pr}_{2} \mathrm{O}(50 \mathrm{ml})$ was added and $\mathrm{pH}$ adjusted to 1.0 with dil. $\mathrm{HCl}$. By extraction with i- $\mathrm{Pr}_{2} \mathrm{O}(3 \times 30 \mathrm{ml})$ hydrochloride of 6 was separated. Organic extracts were washed with dil. $\mathrm{NaHCO}_{3}$, dried, evaporated and crude product crystallized from i- $\mathrm{Pr}_{2} \mathrm{O}(630 \mathrm{mg}, 29 \%)$ m.p. $220-221.5^{\circ} \mathrm{C}$. IR(KBr) $v_{\max } / \mathrm{cm}^{-1}: 1635,1585,1555$, 1540, 1470, 1415, 1330, 1250, 1110, 860, 830, 760. ${ }^{1} \mathrm{H}$ NMR $\left(\mathrm{CDCl}_{3}\right) \delta / \mathrm{ppm}: 3.82(\mathrm{~s}, 6 \mathrm{H}), 5.54(\mathrm{~s}, 1 \mathrm{H}), 6.68-6.54(\mathrm{~m}$, $2 \mathrm{H}), 6.72(\mathrm{~d}, 1 \mathrm{H}, J=9.2 \mathrm{~Hz}), 7.64-7.19(\mathrm{~m}, 6 \mathrm{H}), 15.19$ (s, $1 \mathrm{H}) .{ }^{13} \mathrm{C}$ NMR $\left(\mathrm{CDCl}_{3}\right) \delta / \mathrm{ppm}: 55.9,95.4,103.8,117.5$, $122.1,122.9,123.2,127.3,127.5,129.2,130.7,135.8$, 137.2, 152.6, 157.0.

Anal. Calcd. for $\mathrm{C}_{19} \mathrm{H}_{17} \mathrm{NO}_{3}\left(M_{\mathrm{r}}=307.34\right): \mathrm{C} 74.25, \mathrm{H}$ 5.58, N $4.56 \%$; found: C 74.20, H 5.71, N $4.69 \%$.

\section{1-(R)-Methyl-1-(2,6-dimethoxyphenyl)-2-(2'-quinoli- no)-1-ethylidenebenzylamine (11)}

Compound 6 (172 mg, $0.56 \mathrm{mmol}),(R)$-1-phenylethylamine ( $80 \mathrm{mg}, 0.67 \mathrm{mmol})$, and $\mathrm{Si}(\mathrm{OEt})_{4}(208 \mathrm{mg}, 1.0 \mathrm{mmol})$ were deaerated in toluene $(2.0 \mathrm{ml})$, filtered over basic aluminum oxide, activity I, and then heated in the sealed glass tube at $160{ }^{\circ} \mathrm{C}$ over $66 \mathrm{~h}$. To the cooled reaction mixture $\mathrm{CH}_{2} \mathrm{Cl}_{2}$ $(20 \mathrm{ml})$ was added, and resulting mixture washed with aq. bicarbonate solution. Organic layer was separated, dried, and evaporated, and crude product crystallized on addition of small amount of $\mathrm{MeOH}$. From the mother liquors second crop of $\mathbf{1 1}$ was obtained on evaporation and chromatography on aluminum oxide, activity II-III, with $\mathrm{i}-\mathrm{Pr}_{2} \mathrm{O}$ as eluent. Combined crops were crystallized from EtOH/water and collected on filter at $-20^{\circ} \mathrm{C}(53 \mathrm{mg}, 23 \%)$ m.p. $75-77{ }^{\circ} \mathrm{C}$. $[\alpha]_{\mathrm{D}}=+982\left(c=1 \mathrm{~g} / 100 \mathrm{ml} \mathrm{CH} \mathrm{Cl}_{2}\right) .{ }^{1} \mathrm{H} \mathrm{NMR}\left(\mathrm{CDCl}_{3}\right)$ $\delta / \mathrm{ppm}: 1.57$ (d, $3 \mathrm{H}, J=6.9 \mathrm{~Hz}$ ), 3.26 (s, $3 \mathrm{H}), 3.86(\mathrm{~s}, 3 \mathrm{H})$, $4.28-4.23(\mathrm{~m}, 1 \mathrm{H}), 5.07(\mathrm{~s}, 1 \mathrm{H}), 6.34(\mathrm{~d}, 1 \mathrm{H}, J=8.2 \mathrm{~Hz})$, $6.60(\mathrm{~d}, 1 \mathrm{H}, J=8.2 \mathrm{~Hz}), 6.97(\mathrm{~d}, 1 \mathrm{H}, J=8.7 \mathrm{~Hz})$, $7.80-7.10(\mathrm{~m}, 11 \mathrm{H}), 11.67(\mathrm{~d}, 1 \mathrm{H}, J=7.6 \mathrm{~Hz}) .{ }^{13} \mathrm{C} \mathrm{NMR}$ $\left(\mathrm{CDCl}_{3}\right) \delta / \mathrm{ppm}: 24.9,53.9,55.1,55.8,94.7,103.2,103.5$, $114.9,122.5,122.9,124.7,125.8,125.9,126.0,126.8,127.0$, 127.8, 128.5, 129.6, 133.9, 145.8, 147.3, 149.4, 157.5, 157.7, 160.1 .

Anal. Calcd. for $\mathrm{C}_{27} \mathrm{H}_{26} \mathrm{~N}_{2} \mathrm{O}_{2}\left(M_{\mathrm{r}}=410.51\right)$ : C 79.00, H 6.38, N $6.82 \%$, found: C 79.21, H 6.29, N $6.85 \%$.

\section{Dicarbomethoxy-4-phenyl-1,3-butadiene (13)}

All operations were performed in argon atmosphere; $\mathrm{CH}_{2} \mathrm{Cl}_{2}$ was dried over aluminum oxide (activity I).

To the ice-cold solution of cinnamaldehyde (freshly distilled, $1.65 \mathrm{~g}, 13 \mathrm{mmol})$ in $\mathrm{CH}_{2} \mathrm{Cl}_{2}(20 \mathrm{ml})$ dimethylmalonate (DMM, $3.2 \mathrm{~g}, 2.6 \mathrm{mmol}$ ) was added over $15 \mathrm{~min}$, under stirring, then piperidine (3 drops) and $\mathrm{Na}_{2} \mathrm{SO}_{4}(5.0 \mathrm{~g})$. Reaction mixture was stirred for $24 \mathrm{~h}$ at ambient temperature, solvent evaporated, and yellow oil crystallized on addition of $\mathrm{MeOH}(8.0 \mathrm{ml})$. On standing overnight in refrigerator $1.89 \mathrm{~g}$ $(61.6 \%)$ of 13 was obtained, m.p. $66-68{ }^{\circ} \mathrm{C}$ (lit. m.p. $67{ }^{\circ} \mathrm{C}$ ). ${ }^{23}$ $\mathrm{IR}(\mathrm{KBr}) v_{\max } / \mathrm{cm}^{-1}: 2950,1720,1610,1590,1430,1285,1240$, 1225, 1210, 1060, 750. ${ }^{1} \mathrm{H}$ NMR $\left(\mathrm{CDCl}_{3}\right) \delta / \mathrm{ppm}: 3.81$ (s, $3 \mathrm{H}), 3.89$ (s, 3H), 7.04 (d, 1H, J=15.4 Hz), 7.22-7,58 (m, 7H). ${ }^{13} \mathrm{C}$ NMR $\left(\mathrm{CDCl}_{3}\right) \delta / \mathrm{ppm}: 52.1,52.15,123.1,123.9$, 127.8, 128.7, 129.8, 135.4, 145.1, 153.1, 155.1, 165.6.

\section{1,3-Diphenyl-1-dimethylmalonylprop-2-ene (14)}

$\mathrm{Et}_{2} \mathrm{O}(10.0 \mathrm{ml})$ was added on the Mg-powder (100 mg, 4.1 $\mathrm{mmol})$, then bromobenzene $(319 \mathrm{mg}, 2.0 \mathrm{mmol})$ and catalytic quantity of bromine were added. Reaction mixture was heated $2.5 \mathrm{~h}$ under reflux in argon atmosphere, then cooled to ambient temperature, and solution of diene $\mathbf{1 3}(227 \mathrm{mg}$, $0.9 \mathrm{mmol}$ ) was added dropwise until yellow precipitate was dissolved. Then heating under reflux was continued for $1 \mathrm{~h}$, reaction solution cooled and decanted from the solid residue, washed with std. solution of $\mathrm{NH}_{4} \mathrm{Cl}(10 \mathrm{ml})$, and worked-up as usual. Crude product was purified on silica gel column (15 silica gel), with $\mathrm{n}$-hexane/i- $\operatorname{Pr}_{2} \mathrm{O}(5: 2)$ as eluent; on crystallization from i- $\operatorname{Pr}_{2} \mathrm{O}$ were obtained $230 \mathrm{mg}(77 \%)$ of 14, colourless crystalls, m.p. $94-96{ }^{\circ} \mathrm{C}$ (lit. m.p. $94{ }^{\circ} \mathrm{C}$ ). ${ }^{24}$ IR (KBr) $v_{\max } / \mathrm{cm}^{-1} 2950,1760,1495,1435,1320,1265$, 1145, 745, 705, 690. ${ }^{1} \mathrm{H}$ NMR $\left(\mathrm{CDCl}_{3}\right) \delta / \mathrm{ppm}: 3.52$ (s, $3 \mathrm{H}), 3.70(\mathrm{~s}, 3 \mathrm{H}), 3.96(\mathrm{~d}, 1 \mathrm{H}, J=10.9 \mathrm{~Hz}, 4.24-4.27(\mathrm{~m}$, 1H), 6.34-6.37 (m, 1H), $6.49(\mathrm{~d}, 1 \mathrm{H}), 7.20-7.32(\mathrm{~m} \mathrm{10H})$. 
${ }^{13} \mathrm{C}$ NMR $\left(\mathrm{CDCl}_{3}\right) \delta / \mathrm{ppm}: 49.0,52.2,52.4,57.4,126.3$, 127.1, 127.5, 127.8, 128.4, 128.6, 130.1, 131.7, 140.1, 167.7, 168.2.

\section{Pd-allylation, General Method}

All reactions are performed in the flame-dried vials under argon atmosphere, using standard Schlenk technique. To $[\mathrm{Pd}(\text { allyl }) \mathrm{Cl}]_{2}(2.9 \mathrm{mg}, 7.9 \mu \mathrm{mol})$ dissolved in $\mathrm{MeCN}(1.0$ $\mathrm{ml}$, freshly distilled over $\mathrm{CaH}_{2}$ ), was added ligand (25 $\mu \mathrm{mol})$. Resulting solution was deaerated under argon by repeated evacuation under water-pump, then heated at $50{ }^{\circ} \mathrm{C}$ for $2 \mathrm{~h}$. On cooling to ambient temperature compound $\mathbf{1 5}$ (126 mg, $0.5 \mathrm{mmol}$ ) was added, Schlenk tube was spilled with $\mathrm{MeCN}(0.8 \mathrm{ml})$, then DMM (370 mg, $2.8 \mathrm{mmol})$, BSA $(570 \mathrm{mg}, 2.8 \mathrm{mmol})$ and KOAc $(2.0 \mathrm{mg})$ were added. The reaction went to completeness at $50{ }^{\circ} \mathrm{C}$ overnight. On cooling $\mathrm{CH}_{2} \mathrm{Cl}_{2}(5.0 \mathrm{ml})$ was added, and reaction solution washed with std. aqueous $\mathrm{NH}_{4} \mathrm{Cl}$ solution $(5.0 \mathrm{ml})$. Organic phase was dried, solvent removed and crude product purified by flash chromatography on $30 \mathrm{~g}$ silica gel, with n-hexane/i- $\operatorname{Pr}_{2} \mathrm{O}(5: 2)$ as eluent. Fractions with pure $\mathbf{1 4}$ were collected and evaporated to dryness; determination of yield and e.e. was performed on such chromatographically pure material; HPLC conditions; Chiralcel OD-H column, $25 \times 0.46 \mathrm{~cm}$, pre-column Chiralcel OD, $5.0 \mathrm{~cm}$, eluens n-hexane/i-PrOH (99:1).

\section{RESULTS AND DISCUSSION}

To prepare final ketimines 7-12 in the satisfactory yields, $(R)$-1-arylethylamines and ketones 4-6 were heated in the presence of tetraethoxysilane at $160{ }^{\circ} \mathrm{C}$ under inert atmosphere, Scheme 2. According to the ${ }^{13} \mathrm{C}$ and ${ }^{1} \mathrm{H}$ NMR data, newly prepared bulky ketone $\mathbf{6}$ is present in the solution completely in the enamino-enolic form, as we already observed for similar quinolino-ketones. ${ }^{20,21}$ The signals for the enolic C-atom at $157 \mathrm{ppm}$, and for the $\mathrm{N}-\mathrm{H}$ proton at $15.19 \mathrm{ppm}$, hydrogen bonded to the carbonyl $\mathrm{O}$-atom, can be observed. Besides, the signals for the methylenic $\left(\mathrm{CH}_{2}\right)$ group protons and carbon are absent from the ATP spectra of $\mathbf{6}$.

Improving reported procedures, ${ }^{23,24}$ racemic $\mathbf{1 4}$ was prepared as HPLC standard in $c a .50 \%$ overall yield according to sequence of reactions outlined in the Scheme 3 , and resolved on a Chiralcel OD-H column. Compound 15 was prepared according to the method reported in literature. ${ }^{25}$ Its enantioselective alkylation to the enantiomerically enreached $\mathbf{1 4}$ was performed by the catalytic complexes of 7-12 formed from $\left[\mathrm{Pd}\left(\eta^{3}-\mathrm{C}_{3} \mathrm{H}_{5}\right) \mathrm{Cl}_{2}\right]$, and using a mixture of dimethylmalonate (DMM), $\mathrm{N}, \mathrm{O}$-bis(trimethylsilyl)acetamide (BSA) and potassium acetate to generate malonate anion according to the protocol of Pfaltz et al., ${ }^{26}$ Scheme 4.

After having established general procedure, allylic alkylation was performed with in situ prepared $\mathrm{Pd}^{\mathrm{II}}$ complexes of 7-12. The results presented in the Table I re-

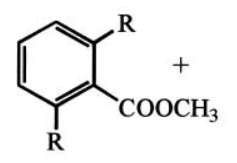<smiles>Cc1ccccn1</smiles><smiles>[R]OCC(C)C(C)C</smiles><smiles>O=C(Cc1ccccn1)c1ccccc1</smiles>

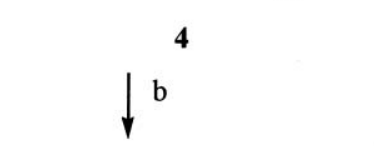<smiles>[R]c1cccc([R])c1C(=O)Cc1ccc2ccccc2n1</smiles>

a) $\mathrm{n}-\mathrm{BuLi} / \mathrm{Et}_{2} \mathrm{O} /-10^{\circ} \mathrm{C}$,

b) $\alpha$ - $(R)$-arylethylamine/ $\mathrm{Si}(\mathrm{OEt})_{4} / p-\mathrm{TsOH} / 160{ }^{\circ} \mathrm{C}$

Scheme 2.<smiles>CC(=O)C(=CC=Cc1ccc(NC=O)cc1)C(C)=O</smiles>

a) $\mathrm{CH}_{2}\left(\mathrm{COOCH}_{3}\right)_{2} /$ pyperidine/ $\mathrm{CH}_{2} \mathrm{Cl}_{2}$ /r.t., b) $\mathrm{PhMgBr} / \mathrm{Et}_{2} \mathrm{O} / \Delta$

Scheme 3.<smiles>CC(=O)O[C@H](/C=C/c1ccccc1)[C@@H](/C=C/c1ccccc1)c1ccccc1</smiles>

a) $[\mathrm{Pd}(\text { allyl }) \mathrm{C}]_{2} / 7-12, \mathrm{DMM}, \mathrm{BSA}, \mathrm{KOH} / \mathrm{MeCN}$

Scheme 4 .

veal the variation of e.e. up to $55 \%$ e.e., comparable with e.e.s obtained with ligands 1a-c (44-69\%). ${ }^{19}$ Large variation of the chemical yield was regularly observed, and is attributed to the sensitivy of the catalytic complex to the trace impurities in the solvent or substrate. 
TABLE I. Enantioselective allylic alkylation of $\mathbf{1 5}$ with dimethyl malonate according to Scheme 4

\begin{tabular}{lcccc}
\hline Entry & Ligand & Yield of $\mathbf{1 4} / \%$ & e.e. / \% & Config. $^{(\text {a) }}$ \\
\hline 1 & $\mathbf{7}$ & 100 & 49.0 & $(R)$ \\
2 & $\mathbf{8}$ & 81 & 55.0 & $(R)$ \\
3 & $\mathbf{9}$ & 14 & 5.5 & $(R)$ \\
4 & $\mathbf{1 0}$ & 26 & 6.7 & $(S)$ \\
5 & $\mathbf{1 1}$ & 97 & 18.0 & $(S)$ \\
6 & $\mathbf{1 2}$ & 17 & 26.0 & $(R)$ \\
\hline
\end{tabular}

${ }^{(a)}$ According to the HPLC data and optical rotation reported in Ref. 26.

Remarkably, in the series 7-12 ligands $\mathbf{1 0}$ and $\mathbf{1 1}$ afford $(S) \mathbf{- 1 4}$, whereas other ligands give $(R)-\mathbf{1 4}$. Reversal of enantioselectivity observed for $\mathbf{1 0}$ and $\mathbf{1 1}$ results from the inversion of the larger and smaller group close to the stereogenic center. In the ligands 7-9 and $\mathbf{1 2}$ aryl group bound to stereogenic center is larger than the heteroaromatic unit, while in the compounds $\mathbf{1 0}$ and $\mathbf{1 1}$ it is smaller then the quinoline moiety. In the recent studies of Moberg et al. ${ }^{27,28}$ such inversion of the enantioselective bias has been reported for 6-substituted pyrido-oxazolines, and explained by the formation of palladium complexes with different conformations. We have therefore compared stable conformations of the previously reported ligands I with those of the ligands $\mathbf{7 - 1 2}$, creating 3D structures optimized by MM2, Figure 1.

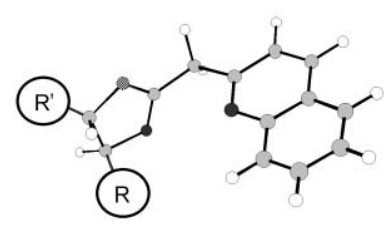

$(4 S, 5 R)-1$

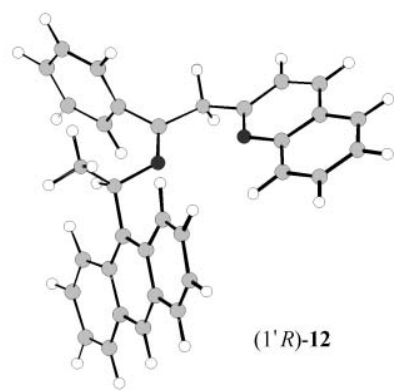

Figure 1. Ball and stick presentation of the lowest energy conformers of (4S)-1 a, and (1'R)-12.

Substantial conformational difference resides in the position of the larger group R; in the ligands 1a-c; it is psudoaxial while in the ligands 7-12 it can adopt various conformations.

In conclusion, we have shown for 1,5-dinitrogen ligands 7-12 that the reactivity and enantioselectivity in allylic alkylation catalyzed by their $\mathrm{Pd}^{\mathrm{II}}$ complexes resambles to those obtained with some structurally related 1,5-dinitrogen ligands. Chiral second sphere around metal atom is invoked to explain the inversion of enantioselectivity with complexes of $\mathbf{1 0}$ and $\mathbf{1 1}$ as compared to the complexes of 7-9 and 12.

Acknowledgements. - The authors acknowledge the help of Mr. Ž. Marinić with the NMR spectra, and of Dr. A. Lesac with MM2 calculations. This work was supported by the Croatian Ministry of Science and Technology (Project No. 980701).

\section{REFERENCES}

1. S.-G. Lee, C. W. Lim, C. E. Song, I. O. Kim, and C.-H. Juan, Tetrahedron: Asymmetry 8 (1997) 2927-2932.

2. A. V. Dedekar, E. B. Koroleva, and P. G. Andersson, J. Org. Chem. 62 (1997) 2518-2526.

3. S. Kanemasa, Y. Oderaotoshi, and D. P. Curran, J. Org. Chem. 62 (1997) 6454-6455.

4. O. Loiseleur, M. Hayashi, N. Schmees, and A. Pfaltz, Synthesis (1997) 1338-1345.

5. J. F. Bower, R. Juminah, A. C. Williams, and J. M. J. Williams, J. Chem. Soc., Perkin Trans. 1 (1997) 1411-1420.

6. B. M. Trost and D. L. van Vranken, Chem. Rev. 96 (1996) 395-422.

7. A. Lightfoot, P. Schneider, and A. Pfaltz, Angew. Chem., Int. Ed. Engl. 37 (1998) 2897-2905.

8. U. Bremberg, M. Larhed, C. Moberg, and A. Hallberg, J. Org. Chem. 64 (1999) 1082-1083.

9. A. Pfaltz, Helv. Chem. Acta 74 (1991) 232-239.

10. G. Helmchen and, A. Pfaltz, Acc. Chem. Res. 33 (2000) 336-345.

11. A. Voituriez, J.-C. Fiuad, and E. Schulz, Tetrahedron Lett. 43 (2002) 4907-4909.

12. G. Cen, X. Li, H. Zhang, L. Gong, A. Mi, X. Cui, Y. Jiang, M. C. K. Choi, and A. S. C. Chan, Tetrahedron: Asymmetry 13 (2002) 809-813.

13. M. Nakoji, T. Kanayama, T. Okino, and Y.Takemoto, J. Org. Chem. 67 (2002) 7418-7423.

14. M. Malkoch, K. Hallman, S. Lutsenko, A. Hult, E. Malmstrom, and C. Moberg, J. Org. Chem. 67 (2002) 8197-8202.

15. D. Šepac, Ž. Marinić, T. Portada, M. Žinić, and V. Šunjić, Tetrahedron 59 (2003) 1159-1167.

16. B. M. Trost and X. Ariza, J. Am. Chem. Soc. 121 (1999) 10727-10737.

17. B. M. Trost, Zh. Pan, J. Zambrano, and C. Kujat, Angew. Chem., Int. Ed. Engl. 41 (2002) 4691-4693.

18. G. J. Dawson, C. G. Frost, C. J. Martin, J. M. J. Williams, and S. J. Coote, Tetrahedron Lett. 34 (1993) 7793-7796.

19. J. M. Canal, M. Gomez, F. Jimanez, M. Rocamora, G. Muller, E. Dunach, D. Franco, A. Jimanez, and F. H. Cano, Organometallics 19 (2000) 966-978.

20. S. I. Kirin, V. Vinković, and V. Šunjić, Chirality 7 (1995) 115-120.

21. Z. Majer, M. Hollosi, S. I. Kirin, and V. Šunjić, Chirality 8 (1996) 244-248.

22. M. Roje and V. Šunjić, Chirality 14 (2002) 625-631.

23. H. Meerwein, Liebigs Ann. Chem. (1908) 323-347.

24. M. Reimer, Am. Chem. J. 38 (1907) 227-237.

25. R. Pamela, B. P. Mackenzie, and B. Bosnich, J. Am. Chem. Soc. 107 (1985) 2033-2046.

26. C. Fahrni, P. V. Matt, and A. Pfaltz, Tetrahedron 48 (1992) 2143-2156.

27. K. Nordstrom, E. Macedo, and C. Moberg, J. Org. Chem. 62 (1997) 1604-1609.

28. M. Svensson, U. Bremberg, K. Hallman, I. Csoregh, and C. Moberg, Organometallics 18 (1999) 4900-4907. 


\section{SAŽETAK}

\section{Uporedni studij 1,5-didušikovih Schiffovih baza kao potencijalnih liganada u paladijem kataliziranoj alilnoj alkilaciji \\ Dragan Šepac, Marin Roje, Zdenko Hameršak i Vitomir Šunjić}

Pripravljeni su 1-(2'-pirido i 2'-kinolino)-(1R)-ariletilamino)-etilideni (7-12) kao potencijalni ligandi u PdII katalitičkim kompleksima za enantioselektivnu alilnu alkilaciju 1,3-difenil-1-acetoksi-propena-2 (15). Alkilacijom uz paladijeve komplekse liganada 7-12 dobiven je 1,3-difenil-dimetilmalonil-propen-2 (14) s enantioselektivnošću do $55 \%$ e.v. Enantioselektivnost je razmatrana u svjetlu nedavno objavljenih rezultata sa strukturno sličnim 1,5-bidentatnim ligandima $C_{1}$ simetrije. Inverzija enantioselektivnosti opažena za ligande $\mathbf{1 0}$ i $\mathbf{1 1}$ objašnjena je inverzijom steričkih zahtjeva u drugoj koordinacijskoj sferi njihovih katalitičkih kompleksa. 